\title{
PENERAPAN MODEL PEMBELAJARAN PROJECT BASED LEARNING DENGAN STRATEGI METAKOGNITIF UNTUK MENINGKATKAN METAKOGNITIF DAN HASIL BELAJAR
}

\author{
Amalia Beladinna Arifa ${ }^{1)}$, Slamet Wibawanto ${ }^{2)}$, I Made Wirawan ${ }^{3)}$ \\ 1,2,3) Program Studi Pendidikan Teknik Informatika, Fakultas Teknik \\ Universitas Negeri Malang \\ Jl. Semarang No. 5, Sumbersari, Kota Malang \\ arifabela@gmail.com ${ }^{1)}$, slamet.wibawanto.ft@um.ac.id ${ }^{2)}$, made.wirawan.ft@um.ac.id ${ }^{3)}$
}

\begin{abstract}
Abstrak
Model pembelajaran berbasis proyek (Project Based Learning) adalah model pembelajaran yang menekankan kegiatan pembelajaran berpusat pada siswa, yang secara kolaboratif dan di bawah pengarahan seorang guru dapat merancang kegiatan, memecahkan masalah, membuat keputusan, melakukan kegiatan serta evaluasi tindak lanjut dan pada akhirnya akan menghasilkan suatu produk nyata. Keterlaksanaan model pembelajaran ini selaras dengan tahapan-tahapan dalam strategi metakognitif. Sehingga melalui pelaksanaan strategi metakognitif yang menyatu pada model pembelajaran berbasis proyek, siswa diharapkan mampu untuk meningkatkan hasil belajar, kemampuan kerjasama, dan kemampuan metakognitif. Penelitian menggunakan pendekatan deskriptif kualitatif yaitu menggambarkan atau mendeskripsikan fenomenafenomena yang sesungguhnya terjadi di lokasi penelitian. Jenis penelitian yang diterapkan termasuk penelitian tindakan kelas (PTK) atau yang disebut Classroom Action Research. Subjek penelitian adalah siswa kelas X TKJ 2 SMK Negeri 5 Malang yang berjumlah 36 orang. Metakognitif siswa diukur dari inventori metakognitif, hasil belajar siswa diukur dari nilai proyek dan posttest. Hasil penelitian menunjukkan bahwa penerapan model pembelajaran Project Based Learning memiliki rata-rata metakognitif 68,10 pada siklus I dan rata-rata metakognitif 71,10 pada siklus II. Serta memiliki ratarata hasil belajar 79,59 dengan persentase ketuntasan siswa sebesar 72,22\% pada siklus I dan rata-rata hasil belajar 84,45 dengan persentase ketuntasan siswa sebesar $94,44 \%$ pada siklus II. Kesimpulan dari hasil penelitian yaitu terdapat peningkatan metakognitif dan hasil belajar siswa kelas X TKJ 2 SMK Negeri 5
\end{abstract}

Malang dengan penerapan model pembelajaran Project Based Learning.

Kata kunci:

Model pembelajaran Project Based Learning, metakognitif, hasil belajar, pemrograman WEB.

\begin{abstract}
Project based learning is a learning model that concerns on student-oriented learning activity, that is done collectively and under the teacher's advice. This learning activity can be done in the forms of arranging activities, resolving problems, making decisions, doing activities, doing further evaluation, and eventually creating concrete products. The accomplishment of this learning model is equal to the steps in metacognitive strategy. Through such strategy that is combined with project based learning, the students are expected to enhance the scores, the ability to cooperate, and metacoginitive skill. This research use Qualitative Descriptive approachthat describes the actual phenomena that occur in the research location. The types of the applied research called Classrom Action Research. The population in this research is the 10th grade of Teknik Komputer Jaringan (TKJ) program in State Vocational High School 5 Malang with the total sample 36 students. The students' metacognitive skill is measured from the metacognitive inventory, while the students' scores are measured by the project scores and post test. The results showed that the applied learning model of Project Based Learning has an average score of metacognitives 68,10 in cycle I and 71,10 in cycle II. The learning model also have an average outcomes of 79,59 with the percentage of completeness $72,22 \%$ in cycle I and 84,45 with the percentage of completeness $94,44 \%$ in cycle II. It concluded that there is
\end{abstract}


improvement in student's metacognitive and scores with the applied learning model Project Based Learning.

Keywords:

Project Based Learning, metacognitive, scores, WEB programming.

\section{Pendahuluan}

Suatu kegiatan pembelajaran dapat dikatakan berhasil apabila tujuan pembelajarannya dapat tercapai. Dalam kegiatan pembelajaran terjadi interaksi antara guru dengan siswa, siswa dengan siswa, sehingga tercipta situasi belajar yang memungkinkan tercapainya tujuan pembelajaran yang telah direncanakan. Seorang guru merupakan tokoh utama dalam proses pembelajaran. Jika guru merencanakan skenario pembelajaran yang menyenangkan, maka siswa akan tertarik pada pembelajaran itu dan ingin mengulangi proses belajar tersebut. Agar pembelajaran yang menyenangkan dapat terlaksana sebagaimana yang diharapkan, maka seorang guru harus memperhatikan secara cermat berbagai faktor yang dapat mempengaruhinya, salah satunya adalah pemilihan model pembelajaran yang tepat. Namun, pemilihan model pembelajaran harus disesuaikan dengan karakteristik mata pelajaran dan karakteristik setiap Kompetensi Dasar yang disajikan.

Pemrograman WEB merupakan salah satu mata pelajaran produktif yang ditempuh siswa kelas $\mathrm{X}$ kompetensi keahlian Teknik Komputer dan Jaringan SMK Negeri 5 Malang. Pada mata pelajaran ini diperlukan adanya pemahaman, kemampuan serta kreatifitas siswa dalam membuat suatu produk berupa WEB. Berdasarkan hasil observasi yang dilakukan pada tanggal 9 dan 16 Oktober 2013, diperoleh kenyataan bahwa pembelajaran yang diterapkan oleh guru adalah guru meminta siswa untuk mempelajari sendiri materi yang sebelumnya telah disampaikan dan membuat sebuah halaman WEB tanpa adanya pedoman materi berupa handout, modul atau buku pendamping, dimana pemahaman teori yang dimiliki oleh siswa sebenarnya masih belum maksimal. Berdasarkan hasil wawancara yang dilakukan pada guru mata pelajaran pemrograman WEB, diperoleh bahwa guru melaksanakan pembelajaran dengan cara konvensional, yaitu menjelaskan materi lalu meminta siswa untuk mempraktekkan hal yang sama yang telah dilakukan oleh guru. Guru juga tidak pernah meminta siswa untuk mengerjakan tugas secara berkelompok, siswa membentuk kelompok belajar sendiri karena untuk memecahkan permasalahan bersama yang diberikan guru. Dan hasilnya terdapat banyak kesamaan antara hasil tugas siswa yang satu dengan yang lainnya.

Model pembelajaran berbasis proyek (Project Based Learning) merupakan sebuah model atau pendekatan pembelajaran inovatif yang berfokus pada konsep-konsep yang melibatkan siswa dalam melakukan pemecahan masalah serta tugas-tugas bermakna lainnya. Pada model pembelajaran Project Based Learning kegiatan pembelajarannya berlangsung secara kolaboratif dalam kelompok yang heterogen. Oleh karena hakikat kerja proyek adalah berkelompok, maka pengembangan keterampilan belajar berlangsung diantara para siswa, yang berarti terjadi suatu aktivitas antar siswa yang satu dengan yang lainnya. Aktivitas tersebut berupa temuan dalam keterampilan merencanakan, mengorganisasikan dan membuat rancangan tugas yang akan dikerjakan, yang pada akhirnya dapat memperkuat kerja tim secara keseluruhan. Melalui model pembelajaran ini, siswa dapat mendapatkan pengalaman belajar yang sesungguhnya karena siswa dapat mengembangkan pola berpikir kritis dan mengambil keputusan dalam memecahkan suatu tugas/permasalahan yang baru ditemukan. Keterlaksanaan model pembelajaran Project Based Learning sejalan dengan tahapantahapan dalam strategi metakognitif. Strategi metakognitif merupakan suatu strategi pembelajaran yang mengacu pada pemantauan terhadap siswa akan kesadaran kognitifnya untuk mencapai suatu tujuan yang ingin dicapai. Tahapan-tahapan dalam strategi metakognitif antara lain tahap merencanakan, tahap monitoring dan membaca, dan tahap evaluasi. Tahapan-tahapan tersebut selaras dengan tahapantahapan yang ada pada model pembelajaran Project Based Learning. Sehingga melalui pelaksanaan strategi metakognitif yang menyatu pada model pembelajaran Project Based Learning, siswa diharapkan mampu untuk meningkatkan hasil belajar, kemampuan kerjasama dan kemampuan metakognitif.

\section{KAJIAN LITERATUR}

\section{II.1 Model Pembelajaran Project Based Learning}

Project Based Learning (PBL) atau pembelajaran berbasis proyek merupakan model pembelajaran yang 
memberikan kesempatan kepada guru untuk mengelola kegiatan pembelajaran di kelas dengan melibatkan kerja proyek (Thomas, 2000). Kerja proyek memuat tugas-tugas yang kompleks berdasarkan kepada pertanyaan dan permasalahan yang menuntut siswa untuk merancang, memecahkan masalah, membuat keputusan, melakukan kegiatan investigasi serta memberikan kesempatan kepada peserta didik untuk bekerja secara mandiri (Wena, 2009). Dalam Project Based Learning, peserta didik didorong untuk menjadi lebih aktif selama aktivitas pembelajarannya, sementara seorang guru/instruktur berfungsi sebagai fasilitator, memberi kemudahan dan mengevaluasi hasil kinerja/proyek baik dalam hal kebermaknaannya maupun penerapannya untuk kehidupan sehari-hari. Produk yang dibuat selama proyek memberikan hasil yang secara otentik dapat diukur oleh guru/instruktur dalam pembelajarannya. Oleh karena itu, seorang guru/instruktur tidak lebih aktif dan melatih secara langsung, akan tetapi lebih kepada mendampingi, memfasilitasi serta memahami pemikiran si peserta didik.

Project Based Learning secara umum memiliki pedoman langkah yang meliputi: Planning (perencanaan), Creating (menciptakan), dan Processing (pengolahan) (Mahanal, 2009).

a. Planning (Perencanaan)

Tahapan ini kegiatan yang dilakukan adalah mempersiapkan proyek, secara lebih rinci mencakup pemberian informasi tujuan pembelajaran, guru menyampaikan fenomena nyata sebagai sumber masalah, pemberian motivasi dalam memunculkan masalah serta pembuatan proposal, dan merencanakan proyek, secara lebih rinci mencakup mengorganisir kerjasama, memilih topik, memilih informasi yang terkait proyek, membuat prediksi dan membuat desain investigasi.

b. Creating (Menciptakan atau Implementasi)

Tahapan ini, peserta didik mengembangkan gagasan proyek, mengkombinasikan ide yang muncul dalam kelompok dan membangun proyek. Pada tahap ini pula peserta didik menghasilkan suatu produk (artefak) yang nantinya akan dipresentasikan dalam kelas.

c. Processing (Pengolahan)

Tahapan ini meliputi presentasi dari proyek dan evaluasi. Pada presentasi proyek akan terjadi komunikasi secara aktual, kreasi ataupun temuan dari investigasi kelompok. Sedangkan pada tahapan evaluasi akan dilakukan refleksi terhadap hasil proyek, analisis dan evaluasi dari prosesproses belajar.

\section{II.2 Metakognitif}

Metakognitif merupakan kata sifat dari metakognisi, secara sederhana metakognisi diartikan sebagai kesadaran seseorang tentang proses berpikirnya pada saat melakukan tugas tertentu kemudian meggunakan kesadarannya untuk mengontrol apa yang dilakukannya (Herman dan Suryadi, 2008). Proses atau keterampilan metakognitif memerlukan operasi mental khusus yang dengannya seseorang dapat memeriksa, merencanakan, mengatur, memantau, memprediksi, dan mengevaluasi proses berpikir mereka sendiri (Weinert dan Kluwe, 1987).

Metakognitif terbagi menjadi 4 kelompok, yaitu metacognitive knowledge, metacognitive experience, tasks and goal, dan strategies or actions (Flavell, 1979). Pengelompokan tersebut dapat dilihat pada Gambar 1.

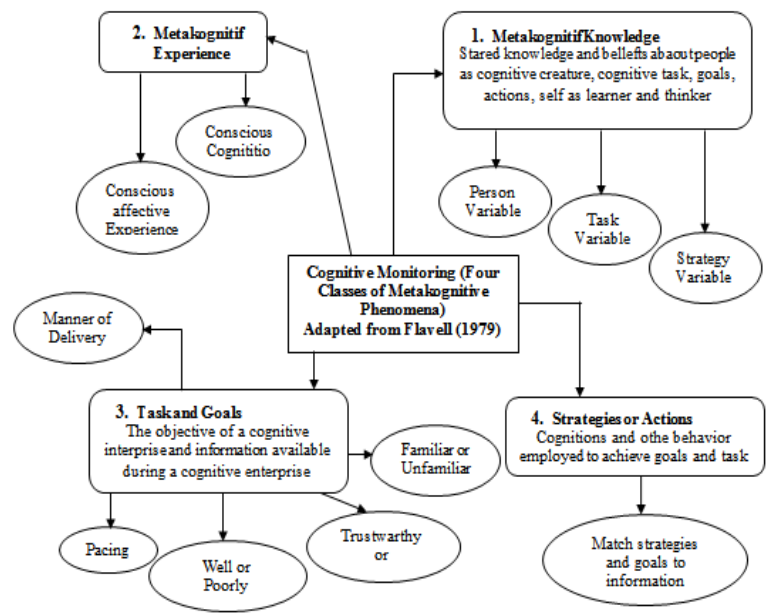

Gambar 1. Mapping Monitoring Metacognitive (Flavell, 1979)

a. Metacognitive Knowledge

Pengetahuan metakognitf merupakan pengetahuan yang diperoleh siswa tentang proses-proses ognitif yaitu pengetahuan yang bisa digunakan untuk mengontrol proses-proses kognitif. 
b. Metacognitive Experience

Pengalaman-pengalaman metakognitif melibatkan strategi-strategi metakognitif atau pengaturan metakognitif.

\section{c. Task and Goals}

Merupakan hasil yang diinginkan atau tujuan usaha kognitif. Tujuan dan tugas meliputi pemahaman, melakukan fakta ke memori, atau menghasilkan sesuatu, seperti dokumen tertulis atau jawaban untuk suatu masalah atau hanya meningkatkan pengetahuan seseorang tentang sesuatu.

\section{d. Strategies or Actions}

Strategi metakognitif merujuk kepada cara untuk meningkatkan kesadaran mengenai proses berfikir dan pembelajaran yang berlaku.

\section{II.3 Keterkaitan antara Model Pembelajaran Project Based Learning dengan Strategi Metakognitif}

Keterkaitan antara model pembelajaran berbasis proyek (Project Based Learning) dengan strategi metakognitif dapat ditinjau dari masing-masing tahapan pelaksanaannya. Tahapan-tahapan tersebut dinyatakan dalam Tabel 1.

Tabel 1. Tahap-tahap Pelaksanaan Model Pembelajaran Project Based Learning dengan Strategi Metakognitif

\begin{tabular}{cll}
\hline \hline No & \multicolumn{1}{c}{$\begin{array}{c}\text { Project Based } \\
\text { Learning }\end{array}$} & \multicolumn{1}{c}{$\begin{array}{c}\text { Strategi } \\
\text { Metakognitif }\end{array}$} \\
\hline \hline 1 & Perencanaan Proyek & Tahap Merencanakan \\
a) & Menghadapkan siswa pada & a) Meminta siswa \\
& masalah riil di lapangan & mempersiapkan diri \\
& Meminta siswa menemukan & dengan cara memilih \\
alternatif dan merumuskan & sumber belajar yang \\
b) & strategi pemecahan masalah & sesuai dengan masalah \\
& Membimbing siswa & dan mampu \\
& melakukan perencanaan & menyelesaikan masalah \\
c) & & tersebut \\
2 & Pelaksanaan Proyek & Tahap Monitoring dalam \\
a) & Membimbing siswa & Membaca \\
& menyelesaikan tugas yang & a) Proses pemantauan \\
& telah didesain pada tahap & terhadap diri sendiri \\
& sebelumnya & ketika membaca dan \\
b) & Membimbing siswa & mengontrol sampai \\
& melakukan pengujian & dimana pemahaman \\
& produk & tentang suatu informasi \\
c) & Membimbing siswa & dalam menyelesaikan \\
& presentasi antar kelompok & masalah \\
3 & Evaluasi Proyek & Tahap Evaluasi \\
a) & Penilaian proyek & a) Merefleksi strategi yang \\
b) & Penilaian produk & digunakan dalam belajar \\
& & sesuai atau tidak \\
\hline \hline & &
\end{tabular}

b) Mengevaluasi ketercapaian tujuan c) Membuat kesimpulan atau rangkuman dari materi

\section{METODE}

\section{III.1 Rancangan}

Penelitian ini menggunakan pendekatan deskriptif kualitatif yaitu menggambarkan atau mendeskripsikan fenomena-fenomena yang sesungguhnya terjadi di lokasi penelitian. Jenis penelitian yang diterapkan termasuk penelitian tindakan kelas (PTK) atau yang disebut Classroom Action Research. PTK merupakan penelitian praktis yang bertujuan yang bertujuan untuk memperbaiki suatu keadaan pembelajaran di kelas dengan melakukan tindakan-tindakan agar terjadi pembaharuan menuju ke arah perbaikan (Arikunto, 2009).

Tindakan yang dilakukan dalam penelitian adalah penerapan model pembelajaran Project Based Learning untuk meningkatkan metakognitif dan hasil belajar kompetensi dasar "Memahami serta Menyajikan Format Kaitan Pada Halaman WEB" dan "Memahami serta Menyajikan Format Tabel Pada Halaman WEB" pada siswa kelas X TKJ 2 SMK Negeri 5 Malang.

Penelitian dilaksanakan dalam 2 siklus sesuai dengan alokasi waktu dan materi pelajaran. Model penelitian tindakan kelas yang digunakan adalah setiap siklus terdiri dari empat langkah, yaitu perencanaan, tindakan, observasi dan refleksi (Basrowi, 2008). Penjabaran dari Gambar 2 adalah (1) sebelum melaksanakan tindakan, terlebih dahulu peneliti harus merencanakan secara seksama jenis tindakan yang akan dilakukan; (2) setelah rencana disusun secara matang, tindakan baru dilakukan; (3) bersamaan dengan dilaksanakannya suatu tindakan, peneliti mengamati proses pelaksanaan tindakan itu dan akbat yang ditimbulkannya; (4) berdasarkan hasil pengamatan tersebut, peneliti kemudian melakukan refleksi atau tindakan yang telah dilakukan jika hasil refleksi menunjukkan perlu dilakukan perbaikan atau tindakan dilaksanakan berikutnya tidak sekedar mengulang apa yang telah dilakukan sebelumnya. Demikian seterusnya hingga masalah yang diteliti dapat dipecahkan secara optimal. 


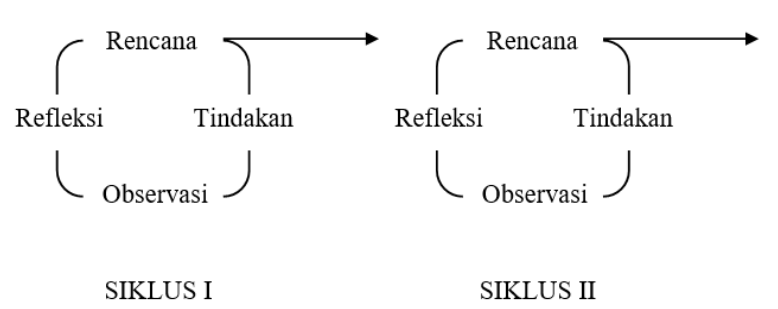

Gambar 2. Rancangan Penelitian PTK (diadopsi dari Kurt Lewin dalam Basrowi, 2008)

\section{III.2 Data dan Sumber Data}

Data yang dikumpulkan antara lain:

a. Metakognitif siswa yang diperoleh melalui angket Metacognitive Awareness Inventory (MAI)

b. Hasil belajar siswa pada ranah kognitif yang diperoleh melalui tes tulis, hasil belajar siswa pada ranah afektif dan psikomotor yang diperoleh melalui rubrik observasi penilaian proyek

c. Sumber data dalam penelitian adalah siswa kelas $\mathrm{X}$ TKJ 2 SMK Negeri 5 Malang dan guru mata pelajaran

\section{III.3 Prosedur Penelitian PTK}

Tahap penelitian tindakan kelas yang dilakukan berupa suatu siklus spiral yang meliputi kegiatan perencanaan, pelaksanaan tindakan, observasi dan refleksi. Tahapan tersebut membentuk siklus demi siklus hingga penelitian selesai.

\section{III.3.1 Siklus I}

\section{III.3.1.1 Perencanaan}

Dalam tahap ini dilakukan penyusunan rencana pembelajaran menggunakan model pembelajaran Project Based Learning. Perencanaan yang dilakukan adalah sebagai berikut:

a. Menyusun langkah-langkah pembelajaran yang dituangkan dalam Rencana Pelaksanaan Pembelajaran (RPP) pada kompetensi dasar "Memahami serta Menyajikan Format Kaitan Pada Halaman WEB".

b. Menyiapkan perangkat dalam penerapan model pembelajaran Project Based Learning, meliputi lembar tugas proyek dan handout.

c. Menyiapkan instrumen pengumpulan data seperti rubrik observasi penilaian proyek, angket MAI, angket keterlaksanaan model pembelajaran
Project Based Learning, dan soal posttest sebagai evaluasi hasil belajar.

\section{III.3.1.2 Pelaksanaan}

Pelaksanaan tindakan pada siklus I direncanakan selama 6x40 menit, dengan dua kali pertemuan. Pembelajaran dilaksanakan dengan menerapkan model pembelajaran Project Based Learning. Pelaksanaan tindakan ini sesuai dengan yang dipaparkan pada skenario pembelajaran siklus I pada Tabel 2.

Tabel 2. Skenario Pembelajaran Siklus I

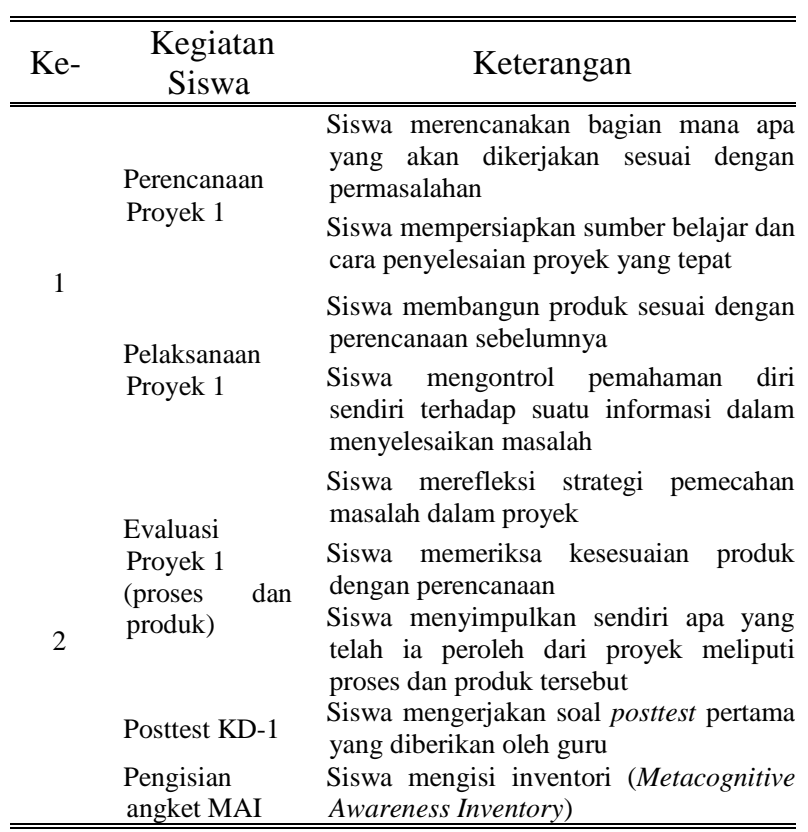

\section{III.3.1.3 Observasi}

Observasi dilakukan selama kegiatan pelaksanaan tindakan berlangsung. Proses pengamatan dilakukan secara seksama oleh peneliti, guru dan observer. Subjek yang diamati oleh pengamatan adalah aktifitas peneliti sebagai guru dalam menerapkan model pembelajaran Project Based Learning, metakognitif siswa dan hasil belajar siswa. Data hasil pengamatan ini dapat dijadikan acuan untuk perbaikan pada siklus II.

\section{III.3.1.4 Refleksi}

Peneliti akan menganalisis data yang diperoleh pada siklus I. Hasil observasi selanjutnya direfleksikan oleh peneliti dan guru untuk mengetahui tingkat ketercapaiannya, baik yang terkait dengan proses maupun hasil tindakan. Refleksi bertujuan 
untuk mengetahui kekuatan-kekuatan yang ditemukan maupun hambatan dalam upaya pencapaian tujuan secara optimal. Hasil refleksi dapat dijadikan acuan untuk merevisi rencana tindakan pada siklus II.

\section{III.3.2 Siklus II}

\section{III.3.2.1 Perencanaan}

Perencanaan yang dilakukan pada siklus II adalah sebagai berikut:

a. Mempelajari hasil refleksi tindakan pada siklus I yang menjadi acuan dalam menyusun perencanaan tindakan untuk perbaikan pada siklus II.

b. Menyusun langkah-langkah pembelajaran yang dituangkan dalam Rencana Pelaksanaan Pembelajaran (RPP) pada kompetensi dasar "Memahami serta Menyajikan Format Tabel Pada Halaman WEB".

c. Menyiapkan perangkat dalam penerapan model pembelajaran Project Based Learning, meliputi lembar tugas proyek dan handout.

d. Menyiapkan instrumen pengumpulan data seperti rubrik observasi penilaian proyek, angket MAI, angket keterlaksanaan model pembelajaran Project Based Learning, dan soal posttest sebagai evaluasi hasil belajar.

\section{III.3.2.2 Pelaksanaan}

Pelaksanaan tindakan pada siklus II direncanakan selama 6x40 menit, dengan dua kali pertemuan. Pembelajaran dilaksanakan dengan menerapkan model pembelajaran Project Based Learning. Pelaksanaan tindakan ini sesuai dengan yang dipaparkan pada skenario pembelajaran siklus II pada Tabel 3.
Tabel 3. Skenario Pembelajaran Siklus II

\begin{tabular}{|c|c|c|}
\hline $\mathrm{Ke}-$ & $\begin{array}{l}\text { Kegiatan } \\
\text { Siswa }\end{array}$ & Keterangan \\
\hline \multirow{2}{*}{3} & $\begin{array}{l}\text { Perencanaan } \\
\text { Proyek } 2\end{array}$ & $\begin{array}{l}\text { Siswa merencanakan bagian mana apa } \\
\text { yang akan dikerjakan sesuai dengan } \\
\text { permasalahan } \\
\text { Siswa mempersiapkan sumber belajar dan } \\
\text { cara penyelesaian proyek yang tepat }\end{array}$ \\
\hline & $\begin{array}{l}\text { Pelaksanaan } \\
\text { Proyek } 2\end{array}$ & $\begin{array}{l}\text { Siswa membangun produk sesuai dengan } \\
\text { perencanaan sebelumnya } \\
\text { Siswa mengontrol pemahaman diri } \\
\text { sendiri terhadap suatu informasi dalam } \\
\text { menyelesaikan masalah }\end{array}$ \\
\hline \multirow{4}{*}{4} & \multirow[b]{2}{*}{$\begin{array}{l}\text { Evaluasi } \\
\text { Proyek } 2 \\
\text { (proses } \\
\text { produk) }\end{array}$} & Siswa merefleksi strategi pemecahan \\
\hline & & $\begin{array}{l}\text { Siswa memeriksa kesesuaian produk } \\
\text { dengan perencanaan } \\
\text { Siswa menyimpulkan sendiri apa yang } \\
\text { telah ia peroleh dari proyek meliputi } \\
\text { proses dan produk tersebut }\end{array}$ \\
\hline & Posttest KD-2 & $\begin{array}{l}\text { Siswa mengerjakan soal posttest pertama } \\
\text { yang diberikan oleh guru }\end{array}$ \\
\hline & $\begin{array}{l}\text { Pengisian } \\
\text { angket MAI }\end{array}$ & $\begin{array}{l}\text { Siswa mengisi inventori (Metacognitive } \\
\text { Awareness Inventory) }\end{array}$ \\
\hline
\end{tabular}

\section{III.3.2.3 Observasi}

Observasi dilakukan selama kegiatan pelaksanaan tindakan berlangsung. Proses pengamatan dilakukan secara seksama oleh peneliti, guru dan observer. Subjek yang diamati oleh pengamatan adalah aktifitas peneliti sebagai guru dalam menerapkan model pembelajaran Project Based Learning, metakognitif siswa dan hasil belajar siswa.

\section{III.3.2.4 Refleksi}

Kegiatan yang dilakukan pada tahap refleksi adalah peneliti akan menganalisis data yang diperoleh pada siklus II. Hasil observasi selanjutnya direfleksikan oleh peneliti dan guru untuk mengetahui tingkat ketercapaiannya, baik yang terkait dengan proses maupun hasil tindakan.

\section{Hasil dan Pembahasan}

\section{IV.1 Data Hasil Siklus I}

\section{IV.1.1 Perencanaan Tindakan}

Perencanaan yang dilakukan pada siklus I adalah menyusun langkah-langkah pembelajaran, menyiapkan perangkat dalam penerapan model pembelajaran, dan menyiapkan instrumen pengumpulan data. Materi yang dipelajari pada siklus I mengenai format kaitan (link) pada halaman WEB. 
Hasil yang dilakukan siswa adalah dapat membuat sebuah produk berupa halaman WEB statis yang menerapkan format kaitan (link) di dalamnya.

\section{IV.1.2 Pelaksanaan Tindakan}

Pelaksanaan tindakan pada siklus I dibagi menjadi dua kali pertemuan. Pada pertemuan pertama, guru menyampaikan materi kurang lebih selama 40 menit, selanjutnya guru memberikan kesempatan kepada siswa untuk bertanya apabila mereka kurang memahami tentang pelajaran yang telah disampaikan. Kegiatan tersebut dalam PBL merupakan tahap Persiapan Proyek. Peran guru yaitu sebagai fasilitator dan mengarahkan siswa sesuai dengan tujuan yang disampaikan. Kemudian dilanjutkan dengan tahap Perencanaan Proyek, yaitu guru membimbing siswa dalam pembentukan kelompok sesuai dengan yang sudah ditentukan dari hasil diskusi dengan guru mata pelajaran pemrograman WEB, yang bertujuan agar pembagian dapat merata. Guru menjelaskan mengenai tugas proyek pertama yaitu membuat halaman WEB statis mengenai profile kelas yang akan dikerjakan siswa dengan kelompoknya masing-masing dan menginstruksikan untuk merencanakan proyek. Selama tahap ini, guru selalu membimbing dan memantau masing-masing kelompok dalam melakukan perencanaan.

Pada pertemuan kedua, guru membimbing siswa dalam mengerjakan pembuatan halaman WEB sesuai yang direncanakan pada pertemuan sebelumnya. Kegiatan tersebut dalam tahapan PBL merupakan Pelaksanaan Proyek. Pada saaat siswa mengerjakan tugas proyek secara berkelompok, guru memantau kegiatan dan mendatangi pada setiap kelompok jika mereka menemui permasalahan dalam pembuatan halaman WEB. Pada tahap ini, terdapat 12 siswa yang mengajukan pertanyaan saat diskusi dalam pembuatan halaman WEB berlangsung. Pada tahap PBL yang terakhir yaitu Presentasi Proyek, guru meminta semua kelompok untuk mempresentasikan hasil pembuatan halaman WEB di depan kelas secara bergantian. Kemudian guru menunjuk beberapa siswa untuk menyimpulkan materi pelajaran yang telah didapatkan pada pertemuan pertama dan kedua sebagai refleksi kegiatan pembelajaran. Sebelum kegiatan pembelajaran berakhir, guru mengadakan posttest yang bertujuan untuk mengukur tingkat pemahaman siswa pada materi pelajaran yang telah disampaikan dan memberikan angket MAI kepada siswa untuk mengukur metakognitif siswa selama proses kegiatan pembelajaran berlangsung.

\section{IV.1.3 Hasil Observasi}

\section{IV.1.3.1 Data Keterlaksanaan Model Pembelajaran Project Based Learning}

Persentase keterlaksanaan model pembelajaran pada siklus I ditunjukkan pada Tabel 4.

Tabel 4. Persentase Keterlaksanaan Model Pembelajaran Siklus I

\begin{tabular}{|c|c|c|c|c|}
\hline Proyek & $\begin{array}{c}\text { Kompetensi } \\
\text { Dasar }\end{array}$ & $\begin{array}{c}\text { Kegiatan } \\
\text { Pembelajaran }\end{array}$ & $\begin{array}{c}\text { Persentase } \\
(\%)\end{array}$ & $\begin{array}{c}\text { Rata-rata } \\
(\%)\end{array}$ \\
\hline \multirow{7}{*}{1} & \multirow{7}{*}{$\begin{array}{l}\text { Format } \\
\text { Kaitan pada } \\
\text { Halaman } \\
\text { Web }\end{array}$} & Pendahuluan & 93,75 & \multirow{7}{*}{92,93} \\
\hline & & $\begin{array}{l}\text { Persiapan } \\
\text { proyek }\end{array}$ & \multirow{5}{*}{92,19} & \\
\hline & & $\begin{array}{l}\text { Perencanaan } \\
\text { tugas proyek }\end{array}$ & & \\
\hline & & $\begin{array}{l}\text { Pemberian } \\
\text { tugas proyek }\end{array}$ & & \\
\hline & & $\begin{array}{l}\text { Pelaksanaan } \\
\text { tugas proyek }\end{array}$ & & \\
\hline & & $\begin{array}{l}\text { Presentasi } \\
\text { tugas proyek }\end{array}$ & & \\
\hline & & Penutup & 92,86 & \\
\hline
\end{tabular}

\section{IV.1.3.2 Data Metakognitif Siswa}

Data metakognitif siswa yang diperoleh dari pemberian angket MAI pada siklus I dapat dilihat pada Tabel 5.

Tabel 5. Deksripsi Data Metakognitif Siswa Siklus I

\begin{tabular}{|c|c|c|c|c|}
\hline Proyek & $\begin{array}{c}\text { Kompetensi } \\
\text { Dasar }\end{array}$ & $\begin{array}{c}\text { Nilai } \\
\text { Terendah } \\
\end{array}$ & $\begin{array}{c}\text { Nilai } \\
\text { Tertinggi } \\
\end{array}$ & $\begin{array}{c}\text { Nilai Rata- } \\
\text { rata } \\
\end{array}$ \\
\hline 1 & $\begin{array}{c}\text { Format } \\
\text { Kaitan pada } \\
\text { Halaman } \\
\text { Web } \\
\end{array}$ & 51,15 & 86,15 & 68,10 \\
\hline
\end{tabular}

\section{IV.1.3.3 Data Hasil Belajar Siswa}

Data hasil belajar siswa diperoleh dari data pelaksanaan kegiatan proyek dengan persentase sebesar $75 \%$ dan data hasil posttest dengan persentase sebesar 25\%. Deskripsi data proses pelaksanaan kegiatan proyek pada siklus I dapat dilihat pada Tabel 6.

Tabel 6. Deksripsi Data Pelaksanaan Kegiatan Proyek Siswa Siklus I

\begin{tabular}{ccccc}
\hline \hline Proyek & $\begin{array}{c}\text { Kompetensi } \\
\text { Dasar }\end{array}$ & $\begin{array}{c}\text { Nilai } \\
\text { Terendah }\end{array}$ & $\begin{array}{c}\text { Nilai } \\
\text { Tertinggi }\end{array}$ & $\begin{array}{c}\text { Nilai Rata- } \\
\text { rata }\end{array}$ \\
\hline \hline \multirow{2}{*}{1} & $\begin{array}{c}\text { Format } \\
\text { Kaitan pada } \\
\text { Halaman } \\
\text { Web }\end{array}$ & 79,84 & 91,10 & 84,64 \\
& & & \\
\hline \hline
\end{tabular}

Data hasil posttest siswa diperoleh dari hasil posttest yang dilakukan pada akhir pembelajaran. Deskripsi data hasil posttest siswa pada siklus I dapat dilihat pada Tabel 7. 
Tabel 7. Deksripsi Data Hasl Posttest Siswa Siklus I

\begin{tabular}{ccccc}
\hline \hline Proyek & $\begin{array}{c}\text { Kompetensi } \\
\text { Dasar }\end{array}$ & $\begin{array}{c}\text { Nilai } \\
\text { Terendah }\end{array}$ & $\begin{array}{c}\text { Nilai } \\
\text { Tertinggi }\end{array}$ & $\begin{array}{c}\text { Nilai Rata- } \\
\text { rata }\end{array}$ \\
\hline \hline \multirow{2}{*}{1} & $\begin{array}{c}\text { Format } \\
\text { Kaitan pada } \\
\text { Halaman } \\
\text { Web }\end{array}$ & 40 & 96 & 64,44 \\
\hline \hline
\end{tabular}

Berdasarkan data pelaksanaan proyek dan data posttest didapatkan data hasil belajar siswa dan dapat diketahui bahwa siswa yang tuntas belajar yaitu yang mendapatkan nilai $\geq 75$ adalah sebanyak 26 orang. Deskripsi data hasil belajar siswa pada siklus I dapat dilihat pada Tabel 8.

Tabel 8. Deksripsi Data Hasil Belajar Siswa Siklus I

\begin{tabular}{cccccc}
\hline \hline Proyek & $\begin{array}{c}\text { Kompetensi } \\
\text { Dasar }\end{array}$ & $\begin{array}{c}\text { Nilai } \\
\text { Terendah }\end{array}$ & $\begin{array}{c}\text { Nilai } \\
\text { Tertinggi }\end{array}$ & $\begin{array}{c}\text { Nilai } \\
\text { Rata- } \\
\text { rata }\end{array}$ & $\begin{array}{c}(\%) \\
\text { Ketunt } \\
\text { asan }\end{array}$ \\
\hline \hline \multicolumn{1}{c}{1} & $\begin{array}{c}\text { Format } \\
\text { Kaitan pada } \\
\text { Halaman } \\
\text { Web }\end{array}$ & 70,88 & 90,04 & 79,59 & 72,22 \\
& & & & & \\
\hline \hline
\end{tabular}

\section{IV.1.4 Refleksi}

Berdasarkan hasil observasi pada pelaksanaan tindakan siklus I, ditemukan beberapa hal yang menjadi catatan sebagai berikut:

a. Siswa belum terbiasa dengan model pembelajaran Project Based Learning, hal ini dikarenakan model pembelajaran yang biasa digunakan adalah pembelajaran konvensional.

b. Pada tahap Persiapan Proyek, guru terlalu cepat dalam memberikan materi pelajaran sehingga terdapat siswa yang kebingungan dan memberikan pernyataan bahwa dia kurang bisa memahami apa yang disampaikan oleh guru.

c. Pada tahap Perencanaan Proyek, siswa merasa kesulitan dalam memahami tugas proyek. Hal ini ditunjukkan dengan seringnya frekuensi siswa bertanya bagaimana membuat perencanaan berupa pembuatan artikel dan desain WEB statis profile kelas.

d. Pada tahap Pelaksanaan Proyek, siswa mulai tertarik dan antusias dalam menyelesaikan tugas proyeknya yaitu berupa pembuatan halaman WEB statis tentang profile kelas, sesuai dengan perencanaan yang telah dilakukan. Meskipun terdapat beberapa siswa yang kurang bertanggung jawab terhadap tugasnya di dalam kelompok. Hal ini dikarenakan karakteristik siswa tersebut yang kurang memiliki antusias terhadap pembelajaran dan kurang memahami perannya di dalam kelompok.

e. Pada tahap Presentasi Proyek, terdapat banyak siswa yang merasa malu untuk tampil mempresentasikan hasil pembuatan halaman WEB kelompoknya di depan kelas.

f. Hasil proyek yang telah diselesaikan pada masing-masing kelompok mempunyai rata-rata yang baik tiap kelompoknya, meskipun terdapat dua kelompok yang tidak tepat waktu dalam menyelesaikan proyeknya.

\section{IV.2 Data Hasil Siklus II}

\section{IV.2.1 Perencanaan Tindakan}

Siklus II merupakan tindakan yang dilakukan dengan melihat beberapa kekurangan pada siklus I, yang bertujuan agar pembelajaran mengalami perubahan menjadi lebih baik. Materi yang dipelajari pada siklus II adalah mengenai format tabel pada halaman WEB. Hasil yang dilakukan siswa adalah dapat membuat sebuah produk berupa halaman WEB statis yang menerapkan format tabel di dalamnya.

\section{IV.2.2 Pelaksanaan Tindakan}

Pelaksanaan tindakan pada siklus II dibagi menjadi dua kali pertemuan. Pada pertemuan ketiga, guru menyampaikan materi kurang lebih selama 40 menit, selanjutnya guru memberikan kesempatan kepada siswa untuk bertanya apabila mereka kurang memahami tentang pelajaran yang telah disampaikan. Kegiatan tersebut dalam PBL merupakan tahap Persiapan Proyek. Kemudian dilanjutkan dengan tahap Perencanaan Proyek, yaitu guru menginstruksikan siswa untuk berkumpul dengan kelompok masing-masing yang telah dibentuk pada pertemuan sebelumnya. Guru menjelaskan mengenai tugas proyek kedua yaitu membuat halaman WEB statis mengenai jadwal pelajaran kelas yang akan dikerjakan siswa dengan kelompoknya masingmasing dan menginstruksikan untuk merencanakan proyek, yaitu berupa pembuatan jadwal pelajaran kelas dan desain halaman WEB yang akan dibuat. Selama tahap ini, guru selalu membimbing dan memantau masing-masing kelompok dalam melakukan perencanaan.

Pada pertemuan keempat, guru membimbing siswa dalam mengerjakan pembuatan halaman WEB sesuai yang direncanakan pada pertemuan sebelumnya. Kegiatan tersebut dalam tahapan PBL 
merupakan Pelaksanaan Proyek. Pada saaat siswa mengerjakan tugas proyek secara berkelompok, guru memantau kegiatan dan mendatangi pada setiap kelompok jika mereka menemui permasalahan dalam pembuatan halaman WEB. Pada tahap ini, masih terdapat siswa yang mengajukan pertanyaan saat diskusi dalam pembuatan halaman WEB berlangsung. Pada tahap PBL yang terakhir yaitu Presentasi Proyek, guru meminta semua kelompok untuk mempresentasikan hasil pembuatan halaman WEB di depan kelas secara bergantian. Kemudian guru menunjuk beberapa siswa untuk menyimpulkan materi pelajaran yang telah didapatkan pada pertemuan ketiga dan keempat sebagai refleksi kegiatan pembelajaran. Sebelum kegiatan pembelajaran berakhir, guru mengadakan posttest yang bertujuan untuk mengukur tingkat pemahaman siswa pada materi pelajaran yang telah disampaikan dan memberikan angket MAI kepada siswa untuk mengukur metakognitif siswa selama proses kegiatan pembelajaran berlangsung.

\section{IV.2.3 Hasil Observasi}

\section{IV.2.3.1 Data Keterlaksanaan Model Pembelajaran Project Based Learning}

Persentase keterlaksanaan model pembelajaran pada siklus II ditunjukkan pada Tabel 9.

Tabel 9. Persentase Keterlaksanaan Model Pembelajaran Siklus II

\begin{tabular}{|c|c|c|c|c|}
\hline Proyek & $\begin{array}{c}\text { Kompetensi } \\
\text { Dasar } \\
\end{array}$ & $\begin{array}{c}\text { Kegiatan } \\
\text { Pembelajaran } \\
\end{array}$ & $\begin{array}{c}\text { Persentase } \\
(\%) \\
\end{array}$ & $\begin{array}{c}\text { Rata-rata } \\
(\%) \\
\end{array}$ \\
\hline \multirow{7}{*}{2} & \multirow{7}{*}{$\begin{array}{l}\text { Format } \\
\text { Tabel pada } \\
\text { Halaman } \\
\text { Web }\end{array}$} & Pendahuluan & 95,83 & \multirow{7}{*}{5,34} \\
\hline & & $\begin{array}{l}\text { Persiapan } \\
\text { proyek }\end{array}$ & \multirow{5}{*}{93,75} & \\
\hline & & $\begin{array}{l}\text { Perencanaan } \\
\text { tugas proyek }\end{array}$ & & \\
\hline & & $\begin{array}{l}\text { Pemberian } \\
\text { tugas proyek }\end{array}$ & & \\
\hline & & $\begin{array}{l}\text { Pelaksanaan } \\
\text { tugas proyek }\end{array}$ & & \\
\hline & & $\begin{array}{l}\text { Presentasi } \\
\text { tugas proyek }\end{array}$ & & \\
\hline & & Penutup & 96,43 & \\
\hline
\end{tabular}

IV.2.3.2 Data Metakognitif Siswa

Data metakognitif siswa yang diperoleh dari pemberian angket MAI pada siklus II dapat dilihat pada Tabel 10.
Tabel 10. Deksripsi Data Metakognitif Siswa Siklus II

\begin{tabular}{ccccc}
\hline \hline Proyek & $\begin{array}{c}\text { Kompetensi } \\
\text { Dasar }\end{array}$ & $\begin{array}{c}\text { Nilai } \\
\text { Terendah }\end{array}$ & $\begin{array}{c}\text { Nilai } \\
\text { Tertinggi }\end{array}$ & $\begin{array}{c}\text { Nilai Rata- } \\
\text { rata }\end{array}$ \\
\hline \hline \multirow{2}{*}{2} & Format & & & \\
& $\begin{array}{c}\text { Tabel pada } \\
\text { Halaman } \\
\text { Web }\end{array}$ & 54,23 & 86,54 & 71,10 \\
& & & \\
\hline \hline
\end{tabular}

\section{IV.2.3.3 Data Hasil Belajar Siswa}

Data hasil belajar siswa diperoleh dari data pelaksanaan kegiatan proyek dengan persentase sebesar $75 \%$ dan data hasil posttest dengan persentase sebesar 25\%. Deskripsi data proses pelaksanaan kegiatan proyek pada siklus II dapat dilihat pada Tabel 11.

Tabel 11. Deksripsi Data Pelaksanaan Kegiatan Proyek Siswa Siklus II

\begin{tabular}{ccccc}
\hline \hline Proyek & $\begin{array}{c}\text { Kompetensi } \\
\text { Dasar }\end{array}$ & $\begin{array}{c}\text { Nilai } \\
\text { Terendah }\end{array}$ & $\begin{array}{c}\text { Nilai } \\
\text { Tertinggi }\end{array}$ & $\begin{array}{c}\text { Nilai Rata- } \\
\text { rata }\end{array}$ \\
\hline \hline \multirow{2}{*}{2} & $\begin{array}{c}\text { Format } \\
\text { Tabel pada } \\
\text { Halaman } \\
\text { Web }\end{array}$ & 84,65 & 94,18 & 88,90 \\
& & & \\
\hline \hline
\end{tabular}

Data hasil posttest siswa diperoleh dari hasil posttest yang dilakukan pada akhir pembelajaran. Deskripsi data hasil posttest siswa pada siklus I dapat dilihat pada Tabel 12.

Tabel 12. Deksripsi Data Hasl Posttest Siswa Siklus II

\begin{tabular}{ccccc}
\hline \hline Proyek & $\begin{array}{c}\text { Kompetensi } \\
\text { Dasar }\end{array}$ & $\begin{array}{c}\text { Nilai } \\
\text { Terendah }\end{array}$ & $\begin{array}{c}\text { Nilai } \\
\text { Tertinggi }\end{array}$ & $\begin{array}{c}\text { Nilai Rata- } \\
\text { rata }\end{array}$ \\
\hline \hline \multirow{2}{*}{2} & $\begin{array}{c}\text { Format } \\
\text { Tabel pada } \\
\text { Halaman } \\
\text { Web }\end{array}$ & 48 & 100 & 71,11 \\
& & & & \\
\hline \hline
\end{tabular}

Berdasarkan data pelaksanaan proyek dan data posttest didapatkan data hasil belajar siswa dan dapat diketahui bahwa siswa yang tuntas belajar yaitu yang mendapatkan nilai $\geq 75$ adalah sebanyak 34 orang. Deskripsi data hasil belajar siswa pada siklus II dapat dilihat pada Tabel 13 .

Tabel 13. Deksripsi Data Hasil Belajar Siswa Siklus II

\begin{tabular}{cccccc}
\hline \hline Proyek & $\begin{array}{c}\text { Kompetensi } \\
\text { Dasar }\end{array}$ & $\begin{array}{c}\text { Nilai } \\
\text { Terendah }\end{array}$ & $\begin{array}{c}\text { Nilai } \\
\text { Tertinggi }\end{array}$ & $\begin{array}{c}\text { Nilai } \\
\text { Rata- } \\
\text { rata }\end{array}$ & $\begin{array}{c}(\%) \\
\text { Ketunt } \\
\text { asan }\end{array}$ \\
\hline \hline \multirow{2}{*}{2} & $\begin{array}{c}\text { Format } \\
\text { Tabel pada } \\
\text { Halaman } \\
\text { Web }\end{array}$ & 74,28 & 94,63 & 84,45 & 94,44 \\
\hline \hline
\end{tabular}




\section{IV.2.4 Refleksi}

Berdasarkan hasil observasi pada pelaksanaan tindakan siklus II, ditemukan beberapa hal yang menjadi catatan sebagai berikut:

a. Siswa mulai terbiasa dengan model pembelajaran berbasis proyek (Project Based Learning). Hal ini ditunjukkan dengan antusias siswa pada saat guru memulai pembelajaran dan selama proses pembelajaran berlangsung.

b. Pada tahap Persiapan Proyek, guru terlalu cepat dalam memberikan materi pelajaran sehingga terdapat siswa yang kebingungan dan memberikan pernyataan bahwa dia kurang bisa memahami apa yang disampaikan oleh guru.

c. Pada tahap Perencanaan Proyek, siswa merasa kesulitan dalam memahami tugas proyek. Hal ini ditunjukkan dengan seringnya frekuensi siswa bertanya bagaimana membuat perencanaan berupa pembuatan artikel dan desain WEB statis profile kelas.

d. Pada tahap Pelaksanaan Proyek, siswa mulai tertarik dan antusias dalam menyelesaikan tugas proyeknya yaitu berupa pembuatan halaman WEB statis tentang profile kelas, sesuai dengan perencanaan yang telah dilakukan. Meskipun terdapat beberapa siswa yang kurang bertanggung jawab terhadap tugasnya di dalam kelompok. Hal ini dikarenakan karakteristik siswa tersebut yang kurang memiliki antusias terhadap pembelajaran dan kurang memahami perannya di dalam kelompok.

e. Pada tahap Presentasi Proyek, terdapat banyak siswa yang merasa malu untuk tampil mempresentasikan hasil pembuatan halaman WEB kelompoknya di depan kelas.

f. Hasil proyek yang telah diselesaikan pada masing-masing kelompok mempunyai rata-rata yang baik tiap kelompoknya, meskipun terdapat dua kelompok yang tidak tepat waktu dalam menyelesaikan proyeknya.

\section{IV.3 Penerapan Model Pembelajaran Project Based Learning Terhadap Peningkatan Metakognitif Siswa}

Pada pelaksanaan tindakan siklus I dalam penerapan model pembelajaran Project Based Learning menunjukkan bahwa rata-rata nilai metakognitif siswa adalah 68,10 dan indikator metakognitif yang mempunyai nilai tertinggi adalah monitoring yaitu sebesar 14\%. Monitoring merupakan kemampuan dalam memonitor atau mengontrol proses belajar dan hal-hal yang berhubungan dengan proses tersebut. Sedangkan pada pelaksanaan tindakan siklus II dalam penerapan model pembelajaran model Project Based Learning menunjukkan bahwa rata-rata nilai metakognitif siswa adalah 71,10 dan indikator metakognitif yang mempunyai nilai tertinggi adalah information management yaitu sebesar $13 \%$. Information management merupakan kemampuan dalam mengelola informasi yang berkenaan dengan proses belajar yang dilakukan.

Penerapan model pembelajaran Project Based Learning menjadikan siswa dapat mengontrol proses belajarnya dan mengatur pemikirannya dalam memecahkan sebuah permasalahan. Hal ini ditunjukkan dengan adanya perubahan siswa dalam kegiatan pembelajaran pada siklus II. Siswa yang pada siklus I membutuhkan adanya bimbingan dari guru karena kemampuannya dalam menerima pembelajaran sangatlah kurang, kemudian memperbaiki kekurangan tersebut pada siklus II. Siswa yang pada siklus I mendapatkan evaluasi dari guru serta merefleksi bersama dengan anggota kelompok tentang tugas proyeknya kemudian memperbaiki kekurangan tersebut pada tugas proyek kedua. Dengan demikian, penerapan model pembelajaran Project Based Learning dapat meningkatkan metakognitif siswa.

\section{IV.4 Penerapan Model Pembelajaran Project Based Learning Terhadap Peningkatan Hasil Belajar Siswa}

Nilai pelaksanaan proyek siswa pada siklus II mengalami peningkatan dari nilai pada proses pelaksanaan proyek siklus I. Begitu pula pada nilai posttest siswa pada siklus II mengalami peningkatan dari nilai posttest siklus I. Kedua hal tersebut berdampak pada nilai rata-rata hasil belajar siswa pada siklus II, yang didapatkan dari nilai pelaksanaan proyek dan nilai posttest, juga mengalami peningkatan dari nilai rata-rata hasil belajar pada siklus I. Meskipun nilai rata-rata klasikal mengalami peningkatan, namun tidak sama halnya dengan nilai yang didapatkan tiap individu siswa. Hal ini terjadi pada nilai posttest, siswa A mendapatkan nilai 68 pada siklus 1 dan meningkat menjadi 80 pada siklus II. Ada juga siswa B yang mendapatkan nilai 96 pada siklus I namun menurun menjadi 84 pada siklus II. Penjelasan tersebut menyatakan bahwa pencapaian 
antara siswa yang satu dengan yang lain memiliki perbedaan, yang didasarkan pada kemampuan masing-masing siswa.

Penerapan model pembelajaran Project Based Learning menjadikan siswa aktif melalui serangkaian kegiatan yang bertujuan untuk membuat suatu produk yang diberikan dalam bentuk tugas proyek, serta siswa lebih kreatif dalam memecahkan suatu permasalahan karena kolaborasi siswa dalam kelompok yang tiap masing-masing siswa mempunyai sumbangan pengetahuan untuk memecahkan permasalahan tersebut. Dampak lain dari penerapan model Project Based Learning adalah penyampaian materi pelajaran yang diterima oleh siswa dengan baik karena model pembelajaran yang diterapkan berbeda dengan yang biasa dilaksanakan, sehingga dapat meningkatkan minat dan perhatian siswa. Dengan demikian, penerapan model pembelajaran Project Based Learning dapat meningkatkan hasil belajar siswa.

\section{KESIMPULAN DAN SARAN}

Berdasarkan uraian pada bab sebelumnya, maka dapat diambil dua kesimpulan. Kesimpulan pertama, penerapan model pembelajaran Project Based Learning dapat meningkatkan metakognitif siswa kelas $\mathrm{X}$ TKJ 2 SMK Negeri 5 Malang. Hal ini dibuktikan dengan nilai metakognitif siswa pada siklus II memiliki rata-rata lebih tinggi dibandingkan dengan nilai metakognitif siswa pada siklus I. Kesimpulan kedua, penerapan model pembelajaran Project Based Learning dapat meningkatkan hasil belajar siswa kelas X TKJ 2 SMK Negeri 5 Malang. Hal ini dibuktikan dengan perolehan masing-masing penilaian hasil belajar pada siklus I, yaitu pelaksanaan proyek dan posttest, memiliki rata-rata lebih tinggi dibandingkan dengan hasil belajar pada siklus II. Perolehan hasil belajar pada siklus I sudah melampaui batas KKM yang ditentukan dan mengalami peningkatan yang lebih baik lagi pada siklus II.

Beberapa saran yang dapat disampaikan adalah guru harus memiliki kemampuan dalam mengenali karakteristik siswa dan karakteristik materi pelajaran yang akan disampaikan sehingga dapat dengan tepat memilih dan menerapkan model pembelajaran pada proses pembelajaran, proses peningkatan kemampuan metakognitif siswa dibutuhkan pembiasaan dengan menerapkan strategi metakognitif dalam proses pembelajaran, dan upaya peningkatan hasil belajar dan metakognitif siswa dapat dikembangkan lagi dengan menggunakan model-model pembelajaran yang lainnya.

\section{REFERENSI}

Arikunto, Suharsimi. (2005). Prosedur Penelitian Suatu Pendekatan Praktik: Edisi Revisi 6. Jakarta.

Flavell, J.H. (1987). Speculations about the nature and development of metacognition. In Weinert, F. E., \& Kluwe, R.H. (Eds.), Metacognition, Motivation, and Understanding. Hillside, NJ.

Herman, T., \& Suryadi, D. (2008). Eksplorasi Matematika: Pembelajaran Pemecahan Masalah. Jakarta.

Mahanal, Susriyati. (n.d). (2009). Pengaruh Pembelajaran Project Based Learning (PjBL) pada Materi Ekosistem terhadap Sikap dan Hasil Belajar Siswa SMAN 2 Malang. Jurnal Universitas Negeri Malang. Malang.

Thomas, J.W., \& Longman, M. J. R. (2000). Managing Project Based Learning: Principles from the Field. Novato, CA.

Weinert, F.E., \& Kluwe, R.H. (1987). Metacognition, Motivation and Understanding. Hilsdale, New Jersey.

Wena, M. (2009). Strategi Pembelajaran Inovatif Kontemporer. Jakarta. 